
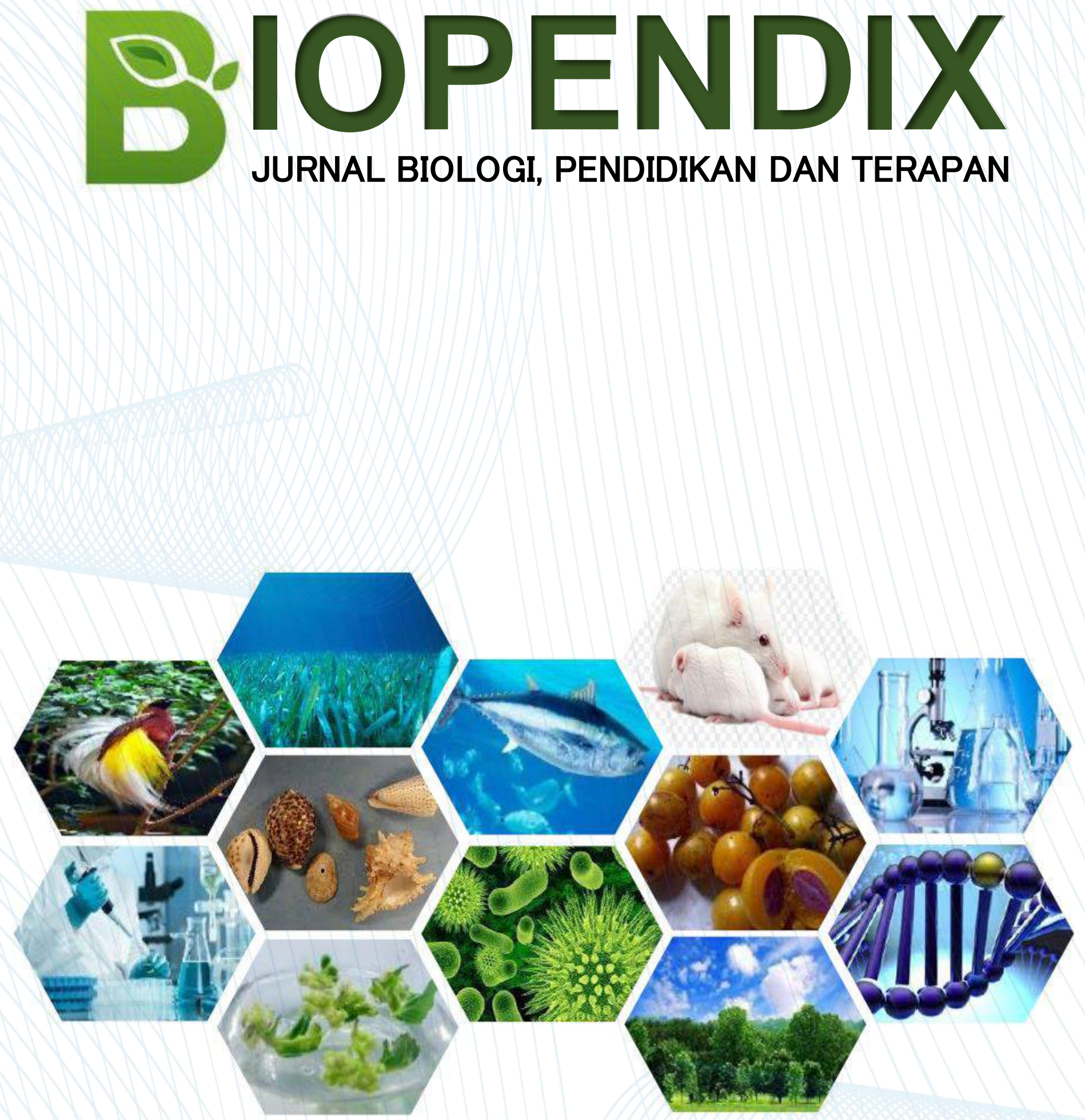

PUBLISHER BY:

BIOLOGY EDUCATION, UNPATTI AMBON - MALUKU 


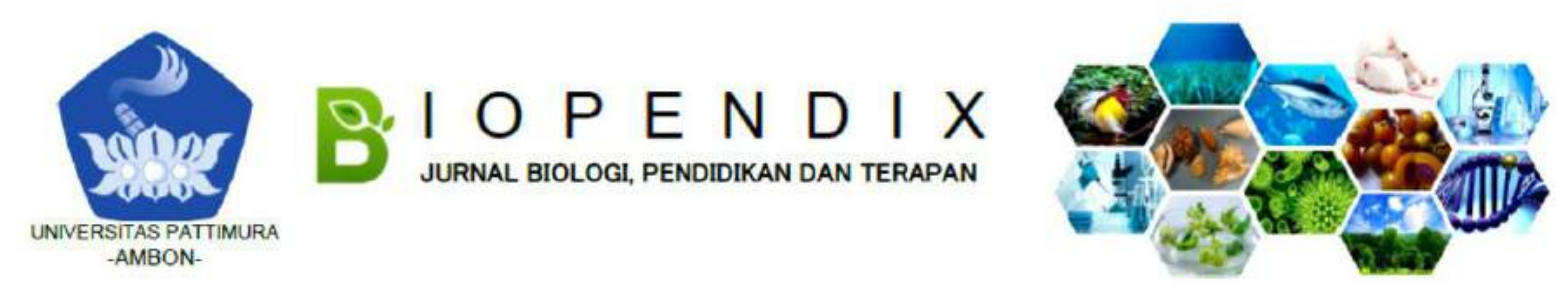

\title{
MODEL PEMBELAJARAN DILI (DISCOVERY LEARNING DAN INQUIRY) DALAM MENINGKATKAN HASIL BELAJAR SISWA SMA NEGERI 7 AMBON
}

\author{
Mariske Kewere $^{1}$, M. Nur Matdoan², Ine Airini ${ }^{\star 2}$ \\ ${ }^{1}$ Alumni Program Studi Pendidikan Biologi; ${ }^{2}$ Program Studi Pendidikan Biologi \\ *Corresponding author: M. Nur Matdoan; e-mail: mnmatdoan.unpatti@gmail.com
}

\begin{abstract}
Background: In achieving a learning goal a teacher is required to be able to choose an effective learning model to be applied in a particular concept. One of the causes of students' lack of understanding of a concept is teacher-centered learning and lack of motivation in students in the learning process. The Discovery Learning and Inquiry learning model is a series of learning activities that maximally involve all students' abilities to search and investigate systematically, critically, logically, analytically, so that they are able to solve the problems themselves with confidence.

Method: This study uses the Discovery Learning and Inquiry learning model on the concept of viruses in class X2 of SMA Negeri 7 Ambon. This research was conducted from 16 February to 16 March 2019.

Results: This study shows that there is an increase in student learning outcomes after using the Discovery Learning learning model that is integrated with the Inquiry model.

Conclusion: From the learning outcomes that are based on the student's final grade shows that there is an increase in the initial test results of students who have not reached the minimum completeness criteria and the final test has reached the minimum completeness criteria (KKM).
\end{abstract}

Keywords: Discovery Learning, Inquiry, Learning Outcomes, Viruses

\begin{abstract}
Abstrak
Latar Belakang: Dalam mencapai suatu tujuan pembelajaran seorang guru di tuntut agar bisa memilih suatu model pembelajaran yang efektif untuk di terapkan dalam konsep tertentu. Salah satu penyebab kurangnya pemahaman siswa terhadap suatu konsep adalah pembelajaran yang terpusat pada guru dan kurangnya motivasi dalam diri siswa dalam proses pembelajaran. Model pembelajaran Discovery Learning dan Inquiry merupakan suatu rangkaian kegiatan belajar yang melibatkan secara maksimal seluruh kemampuan siswa untuk mencari dan menyelidiki secara sistematis, kritis, logis, analitis, sehingga mereka mampu menyelesaikan sendiri masalah yang diberikan dengan penuh percaya diri.

Metode: Penelitian ini menggunakan model pembelajaran Discovery Learning dan Inquiry pada konsep virus di kelas X2 SMA Negeri 7 Ambon. Penelitian ini dilaksanankan dari tanggal 16 februari sampai 16 maret 2019.

Hasil: Penelitian ini menunjukan bahwa terdapat peningkatan terhadap hasil belajar siswa setelah menggunakan model pembelajaran Discovery Learning yang dipadukan dengan model Inquiry.

Kesimpulan: Dari hasil belajar yang berpatokan pada nilai akhir siswa menunjukan bahwa terdapat peningkatan dari hasil tes awal siswa yang belum mencapai kriteria ketuntasan minimal dan tes akhir telah mencapai kriteria ketuntasan minimal (KKM).
\end{abstract}

Kata Kunci: Discovery Learning, Inquiry, Hasil Belajar, Virus 
Biopendix, Volume 6, Nomor 1, Oktober 2019, hlm. 34-39

\section{PENDAHULUAN}

Pendidikan IPA memegang peran penting dalam mengembangkan kemampuan siswa, melalui pendidikan IPA siswa dapat mengenal, menyikapi dan mengapresiasi ilmu pengetahuan dan teknologi serta menanamkan kebiasaan berpikir dan berperilaku ilmiah yang kritis, kreatif dan mandiri. Kecendrungan pembelajaran IPA khususnya biologi pada masa kini adalah peserta didik hanya mempelajari biologi pada produk, menghafalkan konsep teori dan hukum, padahal pada pembelajaran biologi siswa diharapkan dapat memberdayakan kemampuan berpikirnya sehingga dapat mencapai hasil belajar yang tinggi. Biologi sebagai bagian dari pendidikan merupakan salah satu ilmu dasar yang memegang peran penting dalam perkembangan ilmu pengetahuan dan teknologi maupun dalam bentuk kepribadian manusia. Biologi juga menyediakan berbagai pengalaman belajar untuk memahami konsep dan proses sains. Mata pelajaran biologi dikembangkan melalui kemampuan berpikir analitis, induktif, dan deduktif untuk menyelesaikan masalah yang berkaitan dengan peristiwa alam sekitar (BSNP, 2006).

Sanjaya (2010) mengungkapkan bahwa hasil belajar dapat diartikan sebagai pencapaian seorang siswa yang telah melakukan pembelajaran sehingga membuat siswa yang sebelumnya tidak mengerti menjadi mengerti. Hasil belajar dapat dilihat dari tes siswa, lembaran penilaian afektif dan psikomotor. Strategi belajar mengajar terdiri dari model dan teknik (prosedur) yang menjamin tercapainya tujuan pembelajaran. Menurut Suprijono (2011) model Discovery Learning adalah model yang dapat membantu siswa menghubungkan pengalaman yang telah dimiliki dengan pengalaman baru yang dihadapi sehingga siswa menemukan prinsip-prinsip baru. Sedangkan pembelajaran Inquiry mengarahkan siswa untuk menemukan konsep-konsep sains sendiri, artinya, siswa tidak hanya pasif sebagai penerima konsep, melainkan aktif untuk menemukan suatu konsep (Sagala, 2005).

Berdasarkan hasil wawancara yang dilakukan dengan salah satu guru biologi pada SMA Negeri 7 Ambon bahwa hasil belajar siswa kurang baik pada pembelajaran materi Virus. Model maupun metode pembelajaran yang dipakai oleh guru masih bersifat ceramah dan diskusi, sehingga hasil belajar siswa kurang memuaskan hal ini disebabkan karena siswa tidak memiliki media belajar, faktor lingkungan yang kurang memandai, dan kurang pedulinya orang tua terhadap jam belajar siswa sehingga membawa dampak yang kurang baik dalam proses pembelajaran. Faktor-faktor itulah yang menyebabkan hasil belajar siswa yang diperoleh juga kurang baik. Dengan demikian, perlu diterapkan model-model pembelajaran inovatif yang dapat memicu kreativitas terhadap pembelajaran biologi. Berdasarkan latar belakang diatas, maka penulis merasa perlu melakukan penelitian terkait, "Penggunaan Model Pembelajaran Discovery Learning dan Inquiry Untuk Meningkatkan Hasil Belajar Konsep Virus Pada Siswa Kelas X IPA ${ }^{2}$ di SMA Negeri 7 Ambon".

\section{METODE}

Jenis penelitian yang dilakukan dalam penelitian ini adalah jenis penelitian deskriptif, yaitu untuk memberikan motivasi yang lebih baik karena proses belajarnya menuntut siswa aktif, berpikir kritis dan mencari tahu sendiri inti materi pembelajaran yang sedang di pelajari di kelas dengan menggunakan model pembelajaran Discovery Learning dengan model pembelajaran Inquiry untuk meningkatkan hasil belajar siswa pada konsep virus bagi siswa kelas $X \mathrm{IPA}^{2}$ di SMA Negeri 7 Ambon. Penelitian ini dilaksanakan sejak tanggal 16 februari 2019 s/d 16 Maret 2019 yang bertempat di SMA Negeri 7 Ambon.

Subjek dalam penelitian ini adalah seluruh siswa kelas X IPA ${ }^{2}$ program MIPA SMA Negeri 7 Ambon yang berjumlah 24 siswa. Variabel dalam penelitian ini dapat dikelompokan menjadi dua, yaitu variabel bebas (independent variable) dan variabel terikat (dependent variable) (Sugiyono, 2011). Variabel bebas pada penelitian ini adalah model pembelajaran Discovery Learning dan Inquiry merupakan rangkaian kegiatan pembelajaran yang menekankan pada proses berpikir kritis dan analisis 
untuk mencari dan menemukan sendiri jawaban dari suatu masalah yang dipertanyakan sedangkan variabel terikat dalam penelitian ini adalah hasil belajar setelah proses pembelajaran biologi pada konsep virus bagi siswa kelas X IPA ${ }^{2}$ SMA Negeri 7 Ambon.

Data dalam penelitian ini diperoleh dari tes awal, tes formatif, dan observasi untuk mengamati kemampuan afektif dan psikomotor. Data kemampuan kognitif diperoleh lewat hasil LKS yang telah dikerjakan oleh siswa. Data dalam penelitian ini kemudian diolah menggunakan analisis deskriptif.

\section{HASIL DAN PEMBAHASAN}

\section{Tes awal (Pre-test)}

Hasil dari penilitian ini berupa hasil belajar siswa melalui model pembelajaran Discovery Learning dipadukan dengan Model Pembelajaran Inquiry yang diawali dengan tes awal. Tes awal dilakukan dengan tujuan untuk mengetahui sejauh mana pemahaman atau kemampuan siswa kelas $X \quad I A^{2}$ mengenai konsep Virus sebelum mengikuti proses belajar mengajar. Dengan kriteria kentutasan minimal (KKM) yang telah di tetapkan oleh sekolah. Sampel penelitian yakni KKM = 75 . Tes awal dilakukan pada awal pertemuan dikelas. Hasil tersebut kemudian dikonversikan pada table berikut.

Tabel 1. Presentase Hasil Tes Awal Siswa Kelas X2 IPA2 SMA Negeri 7 Ambon Sebelum Penerapan Model Pembelajaran Discovery Learning dan Inquiry

\begin{tabular}{cccc}
\hline Interval & Frekuensi & $\mathbf{( \% )}$ & Kualifikasi \\
\hline$\geq 75$ & 3 & $10 \%$ & Tuntas \\
$\leq 75$ & 21 & $90 \%$ & Gagal \\
\hline Jumlah & $\mathbf{2 4}$ & $\mathbf{1 0 0}$ & \\
\hline
\end{tabular}

Sebelum proses belajar mengajar berlangsung (PBM), pada kelas $X \mathrm{IPA}^{2}$ dilakukan tes awal. Setelah selesai melakukan tes awal ternyata kemampuan awal siswa masih dibawah KKM. Hasil analisis tes awal menunjukan terdapat 3 siswa (10\%) memperoleh nilai pada interval $(\geq 75)$ dengan kualifikasi tuntas dan 21 siswa $(90 \%)$ memperoleh nilai interval $(\leq 75)$ dengan kualifikasi gagal dengan skor maksimum yang diperoleh oleh siswa yaitu, dari KKM yang telah ditetapkan yaitu, 75 . Hal ini membuktikan bahwa pemahaman atau penguasaan konsep sistem virus masih tergolong rendah.

Hal ini disebabkan karena, rendahnya respon siswa pada saat proses pembelajaran (pasif) dan kemampuan berpikir yang berbeda-beda. Tes awal bertujuan untuk memahami sejauh mana kemampuan awal siswa. Kemampuan awal siswa sangat penting diketahui oleh guru sebelum memulai pembelajaran, agar guru dapat mengetahui sejauh mana pemahaman siswa terkait materi yang akan dipelajari. Hal ini sejalan dengan pendapat Suryobroto (1996), yang menyatakan bahwa nilai yang diperoleh adalah nol atau hanya sedikit saja yang menjawab dengan betul, ini dapat dimengerti sebab bahan pembelajaran belum pernah diterapkan.

\section{Deskrisi Penilaian Siswa Selama Proses Belajar Mengajar}

Penilaian terhadap siswa selama proses mengajar dilakukan dengan berpatokan pada 3 aspek yaitu, aspek kognitif, afektif dan psikomotor. Penilaian terhadap aspek kognitif diperoleh dari lembar kerja siswa (LKS) sedangkan aspek efektif dan psikomotor merupakan penilaian secara langsung selama proses belajar mengajar berlangsung.

\section{A. Hasil Penilaian Aspek Kogntif}

Berdasarkan hasil penilitian yang dilakukan pada SMA Negeri 7 Ambon, kemampuan kognitif siswa dalam proses pembelajaran dalam hal ini siswa mengerjakan lembaran kerja siswa (LKS) dan siswa juga melakukan tes akhir (tes formatif) yang digunakan untuk melihat hasil kerja siswa dikelas. Hasilnya dikonvensikan pada Tabel 2 berikut.

\section{Tabel 2. Klasifikasi Penilaian Rata-rata Aspek kognitif}

\begin{tabular}{cccc}
\hline Interval & Frekuensi & $\mathbf{( \% )}$ & Kualifikasi \\
\hline$\geq 75$ & 24 & $100 \%$ & Tuntas \\
$\leq 75$ & - & - & Gagal \\
\hline Jumlah & $\mathbf{2 4}$ & $\mathbf{1 0 0}$ & \\
\hline
\end{tabular}


Berdasarkan tabel 2 diatas diketahui bahwa terdapat 24 orang siswa $(100 \%)$ memperoleh nilai pada interval $(\geq 75)$ dengan kualifikasi tuntas dan tidak terdapat frekuensi siswa yang memperoleh nilai interval ( $\leq 75)$ dengan kualifikasi gagal. Ranah kognitif dikategorikan dalam enam jenjang yaitu, pengetahuan, pemahaman, aplikasi, analisis, sintesis, dan evaluasi. Nuryani (2005) menjelaskan pengukuran hasil belajar harus dirancang sedemikian rupa sehingga dapat diketahui hasil belajar siswa misalnya seperti, pengetahuan mengaplikasikan konsep atau prinsip serta kemampuan berpikir lainya.

Dalam kegiatan belajar mengajar menggunakan model pembelajaran Discovery Learning dipadukan dengan Model Pembelajaran Inquiry ini telah memotivasi dan mendorong siswa untuk berusaha menemukan dan memecahkan permasalahan secara kritis dan bertanggung jawab pada setiap kelompok, tiap kelompok mampu mengerjakan LKS, kemudian siswa secara individu melakukan tes akhir (Tes Formatif) sekaligus dapat membaginya kepada semua siswa. Sehingga pada penilaian aspek kognitif ini menunjukan bahwa 24 siswa (100\%) mencapai ketuntasan belajar. Dari data tersebut terlihat bahwa tingkat pencapaian KKM dari siswa mulai meningkat sehingga mulai menguasai indikator pembelajaran pada konsep yang diajarkan yaitu, konsep Virus.

\section{B. Hasil Penilaian Aspek Afektif}

Data dari penilaian aspek afektif diperoleh dari lembar observasi yang digunakan untuk menilai kemampuan siswa yang meliputi 6 aspek yaitu kejujuran dalam mengerjakan sesuatu, rajin dalam mengerjakan tugas, partisipasi dalam menggemukakan pendapat, penuh perhatian saat mengikuti pelajaran, kerja sama antar sesama teman dan guru, dan bertanggung jawab terdapat apa yang dikerjakan, hasilnya dikonversikan pada Tabel 3 berikut.
Tabel 3. Klasifikasi Presentase Hasil Aspek Afektif

\begin{tabular}{cccc}
\hline Interval & Frekuensi & $\mathbf{( \% )}$ & Kualifikasi \\
\hline$\geq 75$ & 24 & $100 \%$ & Tuntas \\
$\leq 75$ & - & - & Gagal \\
\hline Jumlah & $\mathbf{2 4}$ & $\mathbf{1 0 0}$ & \\
\hline
\end{tabular}

Berdasarkan Tabel 3 pada aspek Afektif, terdapat 24 siswa dengan presentase (100\%) memperoleh nilai pada interval $(\geq 75)$ yang berada pada kualifikasi tuntas, dan tidak terdapat siswa yang memperoleh nilai pada interval $(\leq 75)$ dengan kualifikasi gagal.

Penilaian aspek afektif dalam penilaian berkaitan dengan sikap dan nilai yaitu, mencakup sikap, minat, perasaan, emosi, dan dimana dalam aspek afektif ini diukur kemampuan seorang siswa dilihat dari sikap yang mendukung atau menolak.Tujuan afektif terdiri dari yang paling sederhana yaitu, memperhatikan suatu fenomena sampai kepada yang kompleks dan umumnya berkaitan dengan kepribadian dan hati nurani (Yamin, 2007).

\section{Hasil Penilaian Aspek Psikomotor}

Berdasarkan data hasil penilaian aspek psikomotor dengan menggunakan penilaian proses belajar mengajar yang dinilai berdasarkan 5 aspek penilaian. Hasil dari aspek ini dapat dilihat pada Tabel 4 berikut.

\section{Tabel 4. Klasifikasi Presentase Hasil Aspek Psikomotor}

\begin{tabular}{cccc}
\hline Interval & Frekuensi & $(\%)$ & Kualifikasi \\
\hline$\geq 75$ & 24 & $100 \%$ & Tuntas \\
$\leq 75$ & - & - & Gagal \\
\hline Jumlah & $\mathbf{2 4}$ & $\mathbf{1 0 0}$ & \\
\hline
\end{tabular}

Berdasarkan Tabel 4 untuk aspek Psikomotor, hasilnya terdapat 24 siswa dengan presentase (100\%) memperoleh nilai pada interval $(\geq 75)$ yang berada pada kualifikasi tuntas, dan tidak terdapat siswa yang memperoleh nilai pada interval $(\leq 75)$ dengan kualifikasi gagal.

Pada penilaian aspek psikomotor mencakup kegiatan-kegiatan motorik yang digabungkan dengan kemampuan keterampilan atau kemampuan bertindak 
setelah seseorang menerima pengalaman belajar (Nuryani, 2005).

Keberhasilan pada penilaian aspek afektif dan aspek psikomotor terlihat pada kegiatan belajar mengajar dimana siswa sangat aktif dalam merespon aspek-aspek yang dinilai. Hal ini dikarenakan siswa sendiri yang memecahkan masalah sehingga siswa aktif dalam mengikuti pembelajaran di dalam kelas.

\section{Hasil Tes Formatif (Tes Akhir)}

Tujuan dari adanya hasil belajar siswa untuk mengetahui apakah siswa mampu menguasai indikator pencapaian pada konsep Virus yang diajarkan guru pada proses belajar mengajar. Tes formatif dilaksanakan saat akhir pertemuan. Hasil tersebut dilihat pada Tabel 5 berikut.

Tabel 5. Klasifikasi Presentase Hasil Tes Formatif (Tes Akhir)

\begin{tabular}{cccc}
\hline Interval & $\begin{array}{c}\text { Frekuens } \\
\mathbf{i}\end{array}$ & $\mathbf{( \% )}$ & Kualifikasi \\
\hline$\geq 75$ & 24 & $100 \%$ & Tuntas \\
$\leq 75$ & - & - & Gagal \\
\hline Jumlah & $\mathbf{2 4}$ & $\mathbf{1 0 0}$ & \\
\hline
\end{tabular}

Berdasarkan Tabel 5 terdapat 24 orang siswa dengan presentase (100\%) memperoleh nilai pada interval $(\geq 75)$ yang berada pada kualifikasi tuntas dan tidak terdapat frekuensi siswa yang memperoleh nilai interval $(\leq 75)$ dengan kualifikasi gagal. Hal ini membuktikan bahwa setelah proses belajar mengajar dilakukan dengan menerapkan model Discovery Learning dan Inquiry pada konsep virus hasilnya sangat baik. Dan nilainya mencapai standar KKM sebab model pembelajaran Dicovery Learning yang dipadukan dengan model pembelajaran Inquiry membawa siswa pada situasi masalah yang autentik dan bermakna yang dapat memberikan kemudahan kepada siswa untuk melakukan penyelidikan, mengembangkan inkuiri dan menjadikan pembelajar mandiri serta percaya diri (Ibrahim \& Nur 2000). Hal ini menunjukan bahwa seluruh siswa mampu menguasai materi yang diajarkan dalam proses pembelajaran sehingga dapat disimpulkan bahwa penerapan model pembelajaran Discovery Learning yang dipadukan dengan model pembelajaran Inquiry dapat meningkatkan hasil belajar siswa khususnya pada konsep Virus.

\section{E. Nilai Akhir}

Nilai akhir merupakan hasil belajar siswa yang dapat diketahui dari presentase tingkat penguasaan siswa pada nilai proses dari aspek kognitif, afektif dan psikomotor serta presentase penguasaan siswa pada hasil tes (Tes formatif). Tingkat penguasaan materi setiap siswa berbeda-beda, ini dapat dilihat dari hasil nilai akhir. Data kualifilkasi nilai akhir (NA) dapat dilihat pada Tabel 6 berikut.

\section{Tabel 6. Klasifikasi Presentase Nilai Akhir}

\begin{tabular}{cccc}
\hline Interval & Frekuensi & $\mathbf{( \% )}$ & Kualifikasi \\
\hline$\geq 75$ & 24 & $100 \%$ & Tuntas \\
$\leq 75$ & - & - & Gagal \\
\hline Jumlah & $\mathbf{2 4}$ & $\mathbf{1 0 0}$ & \\
\hline
\end{tabular}

Berdasarkan Tabel 6. nilai akhir, hasilnya menunjukan bahwa hasil akhir yang diperoleh adalah 24 siswa (100\%) memperoleh nilai dengan interval $(\geq 75)$ berada pada kualifikasi tuntas dan tidak terdapat siswa yang memperoleh nilai dengan interval $(\leq 75)$ dengan kualifikasi gagal. Dari hasil yang diperoleh menunjukan bahwa tingkat penguasaan materi oleh siswa melewati kriteria ketuntasan KKM yaitu, 75 .

Nilai akhir adalah nilai berupa angka atau huruf yang melambangkan tingkat keberhasilan peserta didik setelah mereka mengikuti program pendidikan pada jenjang pendidikan tertentu dalam jangka waku yang telah ditentukan. Hasil akhir siswa dalam proses belajar mengajar (PMB) dapat digambarkan bahwa secara keseluruhan siswa berhasil (tuntas). Menurut Mursell (2006), pembelajaran dikatakan berhasil dan berkualitas apabila seluruhnya atau setidak-tidaknya sebagian besar peserta didik terlibat secara aktif, baik fisik, baik mental maupun sosial dalam proses pembelajaran. Pencapaian kompetensi siswa yang meliputi aspek kognitif siswa dari hasil penelitian proses kognitif dalam mengajarkan LKS yang diberikan pada masing-masing kelompok, 
aspek afektif dan aspek psikomotor dapat dilihat pada lembaran penilaian serta hasil tes formatif dapat dilihat pada perolehan nilai akhir (NA) yang memuat tentang hasil pencapaian nilai akhhir siswa yang didapatkan dari penggabungan nilai yang diperoleh siswa kelas $X \mathrm{IPA}^{2}$, maka pencapaian nilai akhir terlihat bahwa 24 siswa berhasil memiliki nilai diatas KKM (75).

Ketuntasan belajar siswa kelas X IPA ${ }^{2}$ SMA Negeri 7 Ambon tidak terlepas dari penggunaan model pembelajaran Discovery Learning dipadukan dengan model pembelajaran Inquiry yang digunakan oleh guru dimana proses ini menunjukan bahwa model pembelajaran Discovery learning dan Inquiry memiliki langkah-langkah pembelajaran yang mampu mendorong siswa dalam proses belajar. Hal ini sejalan dengan pendapat Wenno (2008) yang menyatakan dalam kelompok dengan kemampuan yang heterogen, siswa belajar bersama dengan kelompok kecil yang membantu satu sama lain serta melatih siswa menerima perbedaan pendapat dan bekerja sama dengan teman yang berbeda latar belakangnya.

\section{SIMPULAN}

Berdasarkan hasil penelitian yang diperoleh setelah dilakukan analisis dan pembahasan terhadap masalah yang dikemukakan dalam penelitian ini, maka Yamin. H. M. 2007. Profesional Guru dan Implementasi KTSP. Jakarta: Gaung Presada Press. disimpulkan bahwa model Discovery Learning dan Inquiry mampu meningkatkan hasil belajar siswa pada konsep virus di kelas X IPA ${ }^{2}$ SMA Negeri 7 Ambon.

\section{DAFTAR PUSTAKA}

BSNP. 2006. Peranan pendidikan IPA dalam Dunia Pendidikan. Jakarta: Bumi Aksara.

Ibrahim, M, \& Nur, M. 2000. Pengajaran berdasarkan masalah. Surabaya Unesa University Press.

Mursell. 2006. Mengajar dengan sukses. Jakarta: Bumi Aksara.

Nuryani, R. 2005. Strategi Pembelajaran Mengajar Bologi: Malang UM Press.

Sagala, 2005. Konsep dan Pembelajaran. Bandung: Alfabeta.

Sanjaya, W. 2010. Strategi Pembelajaran Berorientasi Standar Proses Pendidikan. Jakarta: Prenada Media Grup.

Sugiyono. 2011. Statistika untuk Penelitian. Bandung: Alfabeta.

Suprijono, A. 2011. Discovery Learning: Teori dan Aplikasi PAIKEM. Yogyakarta: Pustaka Belajar.

Suryobroto.1996. Mengenal Pengajaran di Sekolah dan Pendekatan Baru dalam Proses Belajar Mengajar. Amanta: Jogjakarta.

Wenno. 2008. Dasar-dasar Proses Belajar Mengajar. Bandung: PT. Bumi Aksara. 